\title{
Thermodynamic cycle with two-component working fluid
}

\author{
Andrey Perminov, Yuri Lukyanov, Sergey Tikhonov, Alexander Ilyin \\ Pskov State University, Electrical engineering faculty, Department of Electric Coupling and \\ Automation System. Address: Pskov, Lenin Square, 2, Russia
}

\begin{abstract}
The article deals with the implementation of the thermodynamic cycle using the two-component working fluid. An estimated calculation of the efficiency of using the two-component working fluid, and a variant implementation of the thermodynamic cycle rotary vane engine with an external heat supply are described.
\end{abstract}

Keywords: thermodynamic cycle, two-component working fluid, rotary-vane engine.

\section{INTRODUCTION}

It is well known that the efficiency of the engines graphically is determined by the area of the working process "compression-expansion" of the working fluid, and the efficiency does not depend on engine design and operating characteristics of the working body.

Real processes in internal combustion engines (gas turbine engines, steam turbines etc.) differ from the ideal process, but in the calculation engines all adhere paradigm proposed by Sadi Carnot - working body participating in a cycle heat engine, always by weight, and is a gas.

The proposed method for producing mechanical motion into a heat engine that uses a loop with twocomponent working body - a new scientific and technical direction.

\section{COMBINED THERMODYNAMIC CYCLE}

There are obvious prerequisites for the assertion that we should expect global change throughout the heat cycle diagram with increasing mass of the working fluid in the expansion stroke and reducing the mass of the working fluid in the compression stroke.

Currently, there are analogs of the thermodynamic cycle, for example, a well-known combined cycle [1, $2,6]$. Combined-cycle plant is a combination of gas turbine and steam turbine plants. A simplified scheme is shown in Fig. 1. In a combustion chamber supplied with fuel and air compressed by the compressor. Combustion products, having worked in a gas turbine enters the heater, which heat the feed water to the boiler, and removed to the atmosphere. The superheated steam produced in the boiler expands in the steam turbine and is condensed in the condenser. The condensate is pumped into the heater, where is heated and then fed into the boiler. Net power generated by gas and steam turbines, generators of electric current is passed.

The ideal cycle of combined-cycle plant in the Tsdiagram is shown in Fig. 2. The cycle is built for $1 \mathrm{~kg}$ of feed water and the amount of gas per $1 \mathrm{~kg}$ of water. Cycle gas turbine plant - 1-2-3-4-5-1, Rankine cycle steam turbine parts - 6-7-8-8'-9-9'-6. With the implementation of separate gas turbine and steam turbine installations heat being applied in the cycle gas turbine plant, measured by the area a-1-2-d, and useful work - an area 1-2-3-4-5. Heat supplied to the steam turbine cycle, measured by the area c-6-7-8-8'-9-f, and useful work - an area 6-7-8-8'-9-9'. The amount of heat measured area 3-5-a-d, given in the useless 3-5 exhaust gases to the environment. In the same apparatus combined cycle heat, represented by the area 3-4-b-d, is given in the 3-4 exhaust gases of the feed water. This area is the area of c-6-7-e (shaded), which determines the amount of heat produced during 6-7 feedwater. Consequently, for the same total power amount of heat supplied to the combined-cycle plant, compared with separate set area decreases by c-6-7-e. This gain in heat consumption and determines the efficiency of combined-cycle plant.

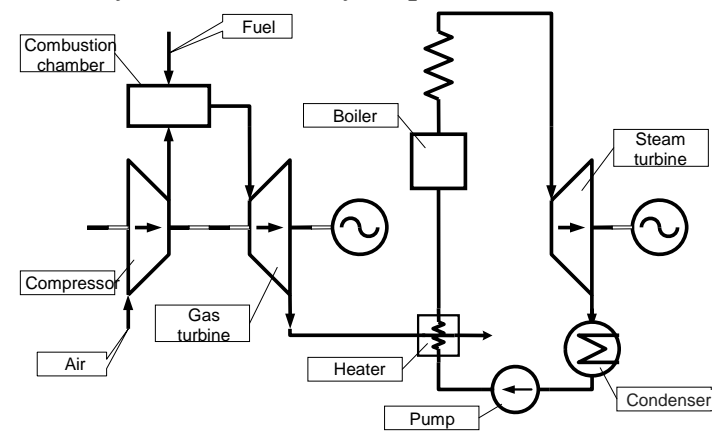

Fig. 1. Scheme of combined-cycle plant. 


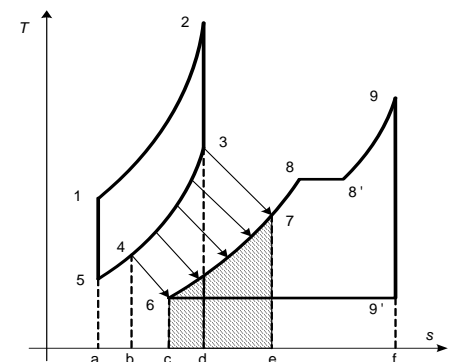

Fig. 2. The ideal cycle of combined-cycle plant.

Indicators of efficiency of modern energy machines are illustrated by the data shown in the Table 1 [2].

TABLE 1.

\begin{tabular}{|l|c|}
\hline \multicolumn{1}{|c|}{ Type of energy machine } & $\begin{array}{c}\text { Efficiency, } \\
\mathbf{\%}\end{array}$ \\
\hline External combustion engines & $25 \ldots 39$ \\
\hline Diesels & $35 \ldots 46$ \\
\hline Jet engines & $15 \ldots 20$ \\
\hline Gas turbines & $30 \ldots 38$ \\
\hline Combined (diesel with gas turbine) & $40 \ldots 45$ \\
\hline Steam turbines with high steam parameters & $36 \ldots 38$ \\
\hline $\begin{array}{l}\text { Combined-cycle (gas and steam turbine) } \\
\text { installation }\end{array}$ & $52 \ldots 60$ \\
\hline
\end{tabular}

For example, the new North-West CHPP - one of the most modern power plants not only in Russia but also in Europe, built using advanced technology combined cycle. This ensures the efficiency of the station at $51.5 \%$, saving up to $20-25 \%$ of fuel and reduce by one third the volume of emissions. The use of scheme of heat output increases the efficiency of the North-West CHP to $76 \%$.

Experiments are known on the water injection at the end of combustion of fuel in an internal combustion engine, resulting in an increased capacity, reduced thermal load on the piston and fuel economy group to $20 \%$, however, the formation of sludge, water in crankcase oil, adversely affect the reliability of operation of the engine in general.

\section{THERMODYNAMIC CYCLE WITH TWO- COMPONENT WORKING FLUID}

Modernization and improvement of engine are doing continuously. The history of development shows that the background of this continuity, there are periods of sharp transition from one to the other types of engines. This has happened in the transition from steam engines to internal combustion engines, the latter to a turbojet aircraft. At the heart of the transition is the change in the thermodynamic cycle of converting thermal energy into mechanical work.

In thermodynamics, known thermal cycles Carnot, Otto, Diesel, Rankine, Stirling et al., based on which are calculated all known engines and their characteristics. Generally, the use of each of these cycles resulted in a significant change in engine design $[3,6,7]$.

Simplified thermodynamic cycle of converting thermal energy into mechanical movement with a two- component working medium in engines with an external supply of heat can be represented as follows (Fig. 3):

1) compressing a first component working fluid-gas mass $M_{1}$ (curve 1-2);

2) introducing a supply of heat to the working cycle of the second component of the body with liquid mass $M_{2}$ transfer of the second component in the gas (line 2-3 ');

3) expanding the gas mixture and obtaining mechanical work (curve 3'-4 ');

4) recovering the condensation heat of the second component of the working fluid in a closed volume (4'-line 1).

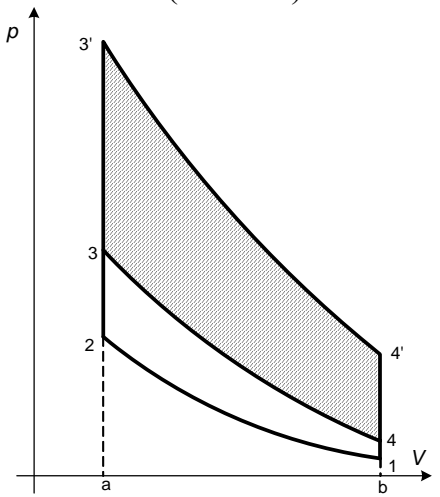

Fig. 3. Thermodynamic cycle with two-component working fluid.

Useful work is measured by area $1-2-3^{\prime}-4$ '. The gain compared to the conventional cycle is square 33'-4'-4 (shaded).

Expansion stroke is an isothermal process with temperature. Then the work of expansion for the first component (Curve 3-4):

$$
A_{E 1}=M_{1} R_{1} T_{E} \ln \left(\frac{V_{E}}{V_{C}}\right),
$$

where $R_{1}$ - gas constant of the first component of the working fluid; $V_{\text {СОL }}$ и $V_{E X P}$ - volumes in collapsed and expanded states.

Job expansion of two-component working medium (curve 3'-4 ')

$$
A_{E 2}=\left(M_{1}+M_{2}\right) R T_{E} \ln \left(\frac{V_{E}}{V_{C}}\right),
$$

where $R=\frac{R_{\mu}}{M_{1}+M_{2}}\left(\frac{M_{1}}{\mu_{1}}+\frac{M_{2}}{\mu_{2}}\right)-$ gas constant twocomponent working fluid.

Thus, one can roughly estimate the increase in the proposed work expansion cycle compared to conventional:

$$
k=\frac{A_{E 2}}{A_{E 1}}=1+\frac{M_{2}}{\mu_{2}} \frac{\mu_{1}}{M_{1}},
$$

where $\mu_{1}$ and $\mu_{2}-$ molar mass of the first and second components. 
For example, if used as the first component of the air, and the second - the water with the same mass, the increase in expansion work will be times. Selection of qualitative and quantitative composition of the working fluid can be achieved a significant increase in this indicator.

\section{CONCLUSION}

This example cycle may be carried out in one engine, which will be its distinction and advantage.

The general scheme of the engine with an external supply of heat $[4,5,8-12]$ using a new cycle is shown in Fig. 4.

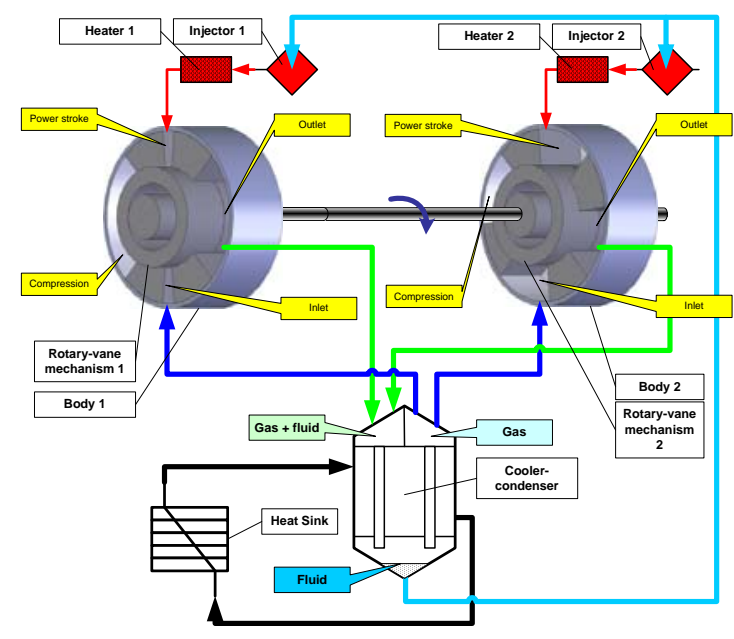

Fig. 4. Scheme of the engine rotary-vane type with external supply of heat and a two-component working fluid.

The first component of the working fluid - gas during the intake stroke flows into the working volume and the contracts. In cycle working stroke by means of the heater nozzle of the second component is added to - liquid heat supply is carried out at high pressure. In the exhaust stroke mixture enters the cooler-condenser, which is cooled and separation of the working fluid into gas and liquid due to condensation. The radiator is used in the coolant circuit to maintain the desired cooling temperature of the working body. Double chamber version of the engine ensures that no dead pixels and the ability to start rotating from any position without the application of an external torque.

It should be noted that when working on the four stroke cycle, the new engine is equivalent to a 16cylinder internal combustion engine with a working volume of the same magnitude.

\section{REFERENCES}

[1] Balian S. V. Technical Thermodynamics and Heat Engines. 1973, p. 132-133.

[2] Sharoglazov BA, Farafontov MF Clement V. Internal Combustion Engines: Theory, modeling and calculation processes. 2004, c. 22.

[3] Stirling engines. Edited by M.G. Kruglov, 1977, c. 124-131.

[4] Patent RU 2387844. Rotary piston engine with heat fed from outside.

[5] Patent RU 2374526. Mechanism for movement transformation.

[6] Ридер Г., Хупер Г. Двигатели Стирлинга. М.: Мир, 1986. $464 \mathrm{c}$

[7] Горожанкин С.A. Определение параметров действительных циклов двигателей Стирлинга на основе их адиабатной модели Современное промышленное и гражданское строительство. Т. 2. № 4. Макеевка: Изд-во Донбасская национальная академия строительства и архитектуры, 2006. С. 187-194.

[8] Zuravlev Y. N., Lukyanov Y. N., Perminov A. L., Ilyin A. V. et al. Mathematical models physical processes in the rotaryvane motor with external heat supply. 2012.

[9] Zuravlev Y. N., Lukyanov Y. N., Perminov A. L., Ilyin A. V. et al. Calculation and design the rotary-vane machine with an external supply of heat. 2012.

[10] Zuravlev Y. N., Lukyanov Y. N., Perminov A. L., Andreev M. L. Autonomous Power Station Based on Rotary-Vane Engine with an External Supply of Heat. Rēzekne: 2013.

[11] Khitrov An., Khitrov Al.Electrical subsystem of the lowpower cogeneration plant with low-speed vehicle. Rēzekne: 2013.

[12] Перминов А. Л., Хитров А. А., Хитров А. И. Мехатронная система «магнито-электрический синхронный двигатель - активный выпрямитель» для автономной системы электроснабжения на базе роторнолопастной машины с внешним подводом тепла. Труды VII Международной (VIII Всероссийской) конференции по автоматизированному электроприводу АЭП-2012: ФГБОУВПО "Ивановский государственный энергетический университет". - Иваново, 2012. - 708 с. с. 330-335 